\title{
Coffee Culture di Indonesia : Pola Konsumsi Konsumen Pengunjung Kafe, Kedai Kopi dan Warung Kopi di Gresik
}

\author{
Nila Yani Hardiyanti ${ }^{1}$, Ratih Puspa ${ }^{1}$ \\ ${ }^{1}$ Departemen Ilmu Komunikasi, Fakultas Ilmu Sosial dan Ilmu Politik, \\ Universitas Airlangga, \\ Jalan Dharmawangsa Dalam No. 4-6 Surabaya, Indonesia 60286 \\ Email: Nila.Yani.2015@fisip.unair.ac.id
}

\begin{abstract}
A B S T R A C T
It is increasingly familiar to see gathering and meeting in various cafes, coffee shops or food stalls in Indonesia. Gathering, hanging out, drinking coffee or the like is done continuously to create a new consumption pattern for the people of Gresik, one of prominent industrial city in Indonesia. The purpose of this study was to determine the consumption patterns of consumers of visitors to cafes, coffee shops, and coffee shops in Gresik. Researchers used the concept of lifestyle consumption patterns, consumer culture, identity and the concept of a "third place" to explain how coffee culture develop and flourish in Gresik. The results of this study include the consumption patterns of consumers of visitors to cafes, coffee shops and coffee shops in the City of Gresik showed some mixed activities. These activities also very diverse from gathering with family, chatting with friends, meeting clients, meeting and working on college or office. Visitors also have their own consumption patterns, with their own choice to spend their time, their spending, and how to achieve pleasure and satisfaction.
\end{abstract}

Keywords: consumption patterns; life styl; cafes; coffee shops; coffee culture.

\section{A B S T R A K}

Dewasa ini kegiatan berkumpul dan melibatkan pembicaraan sering kali dilakukan di Kafe, kedai kopi ataupun warung. Kegiatan berkumpul, nongkrong, ngopi atau semacamnya dilakukan secara terus-menerus hingga menimbulkan sebuah pola konsumsi yang baru bagi masyarakat kota Gresik. Tujuan penelitian ini adalah untuk mengetahui pola konsumsi konsumen pengunjung kafe, kedai kopi, maupun warung kopi di Gresik. Dalam penelitian ini, peneliti menggunakan konsep pola konsumsi gaya hidup, budaya konsumen, identitas dan konsep "third place". Hasil dari penelitian ini meliputi pola konsumsi konsumen pengunjung kafe, kedai kopi dan warung kopi di Kota Gresik memiliki gambaran kegiatan yang bervariasi. Adapun aktivitas yang mereka lakukan juga sangat beragam misalnya berkumpul dengan keluarga, ngobrol dengan temannya, bertemu klien, rapat dan mengerjakan tugal kuliah atau kantor. Selanjutnya juga pengunjung memiliki pola konsumsi masing-masing, pengunjung juga memilih untuk menghabiskan waktunya, biaya yang dikeluarkan serta bagaimana seseorang tersebut dapat mencapai kesenangan dan kepuasan dirinya sendiri saat berada di kafe, kedai kopi ataupun warung kopi.

Kata kunci: pola konsumsi; gaya hidup; kafe; kedai kopi; coffee culture.

\section{A. PENDAHULUAN}

Gresik merupakan sebuah kabupaten yang memiki memiliki banyak perusahaan BUMN seperti PT Semen Indonesia, PT Petrokimia Gresik, PT Wilmar dan beberapa perusahaan lainnya serta beberapa perusahan swasta. Banyaknya perusahaan-perusaan yang berdiri di Kabupaten Gresik menimbulkan adanya urbanisasi. Urbanisasi menurut Ir. Triatno Yudo Harjoko mengatakan bahwa urbanisasi merupakan suatu proses perubahan masyarakat serta kawasan di dalam suatu wilayah yang awalnya non-urban menjadi urban (Harahap, 2013). Budaya ngopi di 
Gresik sudah ada sejak dulu, Ayos (2014) mengungkapkan bahwa awalnya Gresik merupakan wilayah pesisir yang sangat penting, dari sinilah ngopi muncul karena ngopi menjadi sebuah kebutuhan bagi para pelaut yang singgah (Ayos, 2014). Aktivitas meminum kopi yang awalnya adalah sebuah kebutuhan bagi pelaut yang singgah di Gresik, kini menjadi gaya hidup, bahkan sudah diaggap sebagai budaya yang melekat pada masyarakat Gresik. Seiring dengan berkembangnya zaman penikmat kopi pun semakin beragam. Para konsumen kopi saat ini berasal dari berbagai latar belakang, misalnya seperti pekerja atau mahasiswa.

Sejak dulu Gresik memang dikenal dengan kota warung kopi, pasalnya hampir di seluruh sudut kota terdapat warung kopi. Mulai dari di tengah kota, di pinggir hingga di pelosok desa banyak sekali dijumpai warung kopi. Menurut Baihaqi \& Sofyan (2017) pertumbuhan industri di kota Gresik yang cukup padat membuat lahan untuk tempat berkumpul dan melakukan interaksi sangat minim (Baihaqi \& Sofyan, 2017). Oleh sebabnya banyak orang yang akhirnya memanfaatkan warung kopi sebagai tempat untuk bersosialisasi. Bahkan tak jarang di beberapa tempat terdapat warung kopi yang berjejer dan beberapa diantara warung-warung kopi tersebut dapat beroperasi selama 24 jam non-stop. Kemudian menurut Halik et al. (2015) setiap warung kopi di Gresik memiliki keunikan dan kekhasan masing-masing (Halik et al., 2015). Oleh sebabnya pengunjung yang datang berasal dari berbagai kalangan, juga mereka memiliki motivasi yang berbeda-beda pula untuk datang ke warung kopi. Menurut Baihaqi \& Sofyan (2017) kondisi warung kopi seperti ini karena adanya kebiasaan masyarakat kota Gresik yang sangat gemar nongkrong diwarung kopi (Baihaqi \& Sofyan, 2017). Para konsumen warung kopi di kota Gresik juga sangat beragam baik dari tua, muda, mahasiswa, buruh, pedagang hingga wakil rakyat, pejabat, ulama, pengusaha juga aparat. Selain itu, warung kopi juga digunakan untuk tempat rapat dan membicarakan hal-hal penting seperti politik, sosial hingga urusan pribadi. Bahkan segala transaksi usaha juga banyak dijumpai di warung-warung kopi di Gresik, seperti halnya jual beli kendaraan, penawaran properti, dan segala jenis perdagangan lainnya.

Saat ini bentuk penyajian kopi dapat dilakukan dengan berbagai cara yang inovatif dan kreatif. Penyajian kopi saat ini bukan hanya sekedar menyampurkan bubuk kopi dengan gula dan air panas lalu diaduk, namun penyajian kopi telah jauh berbeda dan telah berkembang sangat modern. Seiring dengan berkembangnya aneka teknik pembuatan kopi, penjualan kopi pun meningkat sehingga membuat aktivitas meminum kopi kini sudah menjadi gaya hidup. Menurut Sjahroni et al. (2019) konsep gaya hidup adalah sebuah pola hidup yang menentukan bagaimana individu memilah untuk menggunakan waktunya, energi, dan uang serta bagaimana individu merefleksikan nilai, kesenangan beserta rasa (Sjahroni et al., 2019). Sedangkan pola konsumsi adalah susunan kebutuhan individu terhadap barang dan jasa yang akan dikonsumsi dalam jangka waktu tertentu. Setiap individu memiliki pola konsumsi yang berbeda-berbeda. Tentunya orang yang berpenghasilan lebih tinggi akan memiliki pola konsumsi yang berbeda dengan orang yang memiliki penghasilan lebih rendah. Jika urban dikaitkan dengan konsep pola konsumsi, maka hal tersebut merupakan sebuah bentuk identitas individu yang mana mengindikasikan bahwa setiap individu mempunyai kebebasannya tersendiri untuk menentukan perilaku yang menjadi gaya hidupnya (Sunajaya, 2017). Sedangkan salah satu aktivitas hidup yang identik dengan masyarakat urban saat ini adalah kegiatan berkumpul dan melibatkan pembicaraan dengan satu sama lain (nongkrong) di kafe, kedai kopi, maupun di warung-warung kopi. Selain digunakan sebagai tempat berkumpul dengan kerabat, baik kafe, kedai kopi, maupun di warung kopi saat ini juga digunakan sebagai titik temu dengan kolega kerja sekaligus tempat berdiskusi mengenai bisnis. 
Salah satu aktivitas yang sangat identik dengan masyarakat urban lifestyle saat ini adalah kegiatan berkumpul dan melibatkan penbicaraan di dalamnya (nongkrong). Menurut Zukin makna gaya hidup perkotaan yaitu pencarian modal kebudayaan (cultural capital) yang mengembangkan tingkat konsumsi ruang-ruang yang dianggap trendi atau baru, misalnya seperti restoran dan coffe bar (Sunajaya, 2017). Aktivitas nongkrong merupakan sebuah pola ragam budaya yang saat ini sedang eksis di Indonesia. Keberagaman pola tersebut dapat ditinjau melalui sikap, nilai dan cara hidup suatu kelompok tertentu, hal ini dipahami menjadi sebuah bentuk aktivitas tertentu yang sudah menjadi kebiasaan yaitu aktivitas nongkrong (Fauzi et al., 2017). Dari sinilah terlihat bahwa dalam mengunjungi sebuah kedai kopi masyarakat urban tidak hanya sekedar membeli produk yang dijual di kedai kopi tersebut, melainkan juga adanya konsumsi ruang publik atau ruang kedai tersebut berdasarkan tujuannya. Menurut Fauzi et al. (2017) mengatakan bahwa Baudrillad menunjukkan bahwa masyarakat urban tidak lagi hidup berdasar pada pertukaran barang dengan nilai guna, namun bergantung pada komoditas sebagai nilai tanda dan simbol yang dalam menggunakannya bersifat sewenang-wenang (Fauzi et al., 2017). Sedangkan menurut Putranto dalam dalam kehidupan masyarakat urban yang dianggap konsumtif, masyarakat mudah mendapatkan kenikmatan atau kesenangan dengan membeli atau mengonsumsi sebuah sistem tanda yang dimiliki bersama (a share system of sign) (Fauzi et al., 2017).

\section{B. METODE PENELITIAN}

Pendekatan penelitian yang digunakan dalam penelitian ini adalah pendekatan kualitatif. Menurut Anggito \& Setiawan (2018) mengatakan bahwa "penelitian kualitatif banyak digunakan dalam bidang sosial. Penelitian kualitatif merupakan suatu penelitian yang hasil penelitiannya tidak diperoleh melalui prosedur statistik atau metode kuantifikasi yang lain. Peneliti biasanya menggunakan naturalistik untuk memahami suatu fenomena tertentu" (Anggito \& Setiawan, 2018). Tipe penelitian yang digunakan dalam penelitian ini adalah penelitian eksploratif. Dalam penelitian ini, penelitia akan menggunakan tipe penelitian eksploratif karena peneliti tidak hanya akan menjelaskan, namun peneliti juga akan mengeksplorasi hal-hal yang berkaitan dengan pola konsumsi konsumen pengunjung kedai kopi di Gresik. Sedangkan metode yang dilakukan dalam penelitian ini adalah studi kasus. Metode studi kasus ini merupakan salah satu metode yang digunakan dalam ilmu sosial. Menurut Creswell (2014) menyebutkan bahwa studi ini dalam pendekatan kualitatif lebih kepada menggunakan kata-kata seperti mengeksplorasi (Creswell, 2014).

Kemudian penelitian mengenai pola konsumsi konsumen pengunjung kedai kopi di Gresik ini akan dilakukan di Kabupaten Gresik, beberapa kedai kopi yang akan di sasar oleh peneliti diantaranya adalah Exelco, Kene Kopi, dan warung Cak Ri. Teknik pengumpulan data yang digunakan yaitu dengan memperoleh catatan lapangan terhadap perilaku dan aktivitas narasumber di lokasi penelitian. Nantinya catatan lapangan yang diperoleh akan dicatat atau direkam oleh peneliti yang mana menggunakan beberapa pertanyaan yang sebelumnya telah dirumuskan oleh peneliti. Dalam penelitian ini, peneliti akan menggunakan teknik pengumpulan data wawancara dan observasi. Penelitian ini juga melakukan observasi terhadap hal-hal yang berhubungan dengan "third place", diantaranya yakni desain interior dan dekorasi, pengimplikasian komunitas lokal, barista dan observasi singkat kepada pemilik. Penentuan 
informan yang akan dipilih dalam penelitian ini adalah pengunjung kedai-kedai kopi yang tersebar di Kota Gresik. Nantinya kedai kopi yang dipilih peneliti akan meliputi kafe, kedai kopi dan warung kopi. Dari masing-masing kedai kopi tersebut nantinya peneliti akan mengambil tiga sampel informan untuk memperoleh informasi terkait. Informan juga akan berasal dari berbagai latar belakang usia, status ekonomi sosial, dan gender.

Tabel 1. Profil Informan

\begin{tabular}{ccc}
\hline Excelso & Kene Kopi & Warung Kopi Cak Ri \\
\hline $\begin{array}{c}\text { Fandi Akhmad Yani } \\
\text { Ketua DPRD Kota Gresik } \\
\text { periode 2019 }-2024 .\end{array}$ & Raka Rusidy \\
Usia 35 tahun. & $\begin{array}{c}\text { Penjaga toko pakaian } \\
\text { Usia 23 tahun. }\end{array}$ & $\begin{array}{c}\text { Mbarek Mijil Pamungkas } \\
\text { Mahasiswa }\end{array}$ \\
Mariyatin & & Usia 22 tahun. \\
Ibu rumah tangga & Shafira Monica Rahmayanti & M. Ali Faisal \\
Usia 47 tahun. & Mahasiswa & Mahasiswa dan Pengusaha \\
Nur Rahmad Yani & Usia 22 tahun. & Usia 22 tahun. \\
Pengusaha & Wika Ifananda & Alif Najamuddin \\
Usia 26 tahun. & Siswi kelas 3 SMAN 1 Gresik & Pengusaha \\
& Usia 18 tahun. & 24 tahun.
\end{tabular}

Sumber: Hasil Wawancara Penelitian

\section{HASIL DAN PEMBAHASAN}

Data dalam penelitian ini berasal dari hasil wawancara mendalam dengan sembilan informan yang sudah dikelompokkan menjadi tiga bagian. Hasil penelitian ini meliputi pola konsumsi konsumen pengunjung cafe, pola konsumsi konsumen pengunjung kedai kopi, dan pola konsumsi konsumen warung kopi.

Menurut Dhohiri (2007) kegiatan konsumsi yaitu saat seseorang menggunakan, memakai, dan memanfaatkan barang atau jasa untuk memenuhi kebutuhan hidupnya (Dhohiri, 2007). Sedangkan pola konsumsi adalah susunan kebutuhan individu terhadap barang dan jasa yang akan dikonsumsi dalam jangka waktu tertentu. Setiap individu memiliki pola konsumsi yang berbeda-berbeda. Tentunya orang yang berpenghasilan lebih tinggi akan memiliki pola konsumsi yang berbeda dengan orang yang memiliki penghasilan lebih rendah. Salah satu aktivitas yang sangat identik dengan masyarakat urban lifestyle saat ini adalah kegiatan berkumpul dan melibatkan penbicaraan di dalamnya (nongkrong). Menurut Zukin makna gaya hidup perkotaan yaitu pencarian modal kebudayaan (cultural capital) yang mengembangkan tingkat konsumsi ruang-ruang yang dianggap trendi atau baru, misalnya seperti restoran dan coffe bar (Sunajaya, 2017).

Jika konsep pola konsumsi dikaitkan dengan penelitian ini, aktivitas meminum kopi yang awalnya adalah sebuah kebutuhan bagi pelaut yang singgah di Kota Gresik, sekarang menjadi gaya hidup, bahkan masyarakat setempat menganggap aktivitas ngopi sebagai budaya yang melekat bagi masyarakat Kota Gresik. Namun, apabila dulu kopi hanya dapat dinikmati di warung-warung kecil pinggir jalan, kini seiring dengan berkembangnya zaman dan lahirnya 
masyarakat urban, para penikmat kopi dapat menikmati secangkir kopi dengan cara yang berbeda. Saat ini banyak di jumpai kafe-kafe yang mengusung konsep modern yang mana dapat menawarkan sensasi berbeda saat orang-orang ingin menikmati secangkir kopi, salah satunya adalah kafe Excelso.

Berdasarkan hasil wawancara dari beberapa informan mengenai pola konsumsi konsumen pengunjung kafe khususnya di Excelso, tentu para individu tersebut dapat menggambarkan bahwa mereka memilih menghabiskan waktu untuk nongkrong atau melakukan aktivitas ngopi di sebuah kafe. Menurut informan yang peneliti pilih yang mana mereka termasuk golongan berstatus ekonomi sosial menengah ke atas, mereka selalu mengedepankan aspek kenyamanan dan kualitas produk yang bagus. Kenyamanan disini mereka peroleh melalui desain interior dan dekorasi kafe, konsumen pengunjung kafe selalu memperhatikan pemilihan kursi dan meja, dekor dinding, hiasan di sekitar kafe, alunan musik juga ruangan yang dingin.

"Excelso menyajikan tempat yang luar biasa termasuk pemilihan kursi, terus dekor dinding atau tempat-tempat bunga dalam ruangan. Itu menjadikan nilai lebih buat Excelso yang mana tidak hanya kita datang meminum kopi tapi ada suasana baru yang dirasakan oleh konsumen." (Informan 1, Gus Yani, Wawancara, Jumat, 27 Maret 2020).

"Tentunya coffee shop yang bersih, ya. Bersih, dingin terus baunya wangi, bau kopi itu juga enak. Itu yang bisa dirasa nyaman bagi konsumen" (Informan 1, Gus Yani, Wawancara, Jumat, 27 Maret 2020).

Bahkan tak jarang dari mereka yang sengaja memilih duduk di sofa demi kenyamanan saat berada di kafe. Begitupun juga untuk kualitas produk, pengunjung kafe juga memperhatikan kualitas produk saat mereka mengunjungi kafe, kualitas yang tidak diragukan bahkan cenderung konsisten juga menjadikan alasan utama mereka memilih kafe sebagai tempat nongkrong.

Adapun informan tersebut datang ke kafe utamanya untuk rapat organisasi, bertemu rekanan kerja, menghabiskan waktu dengan keluarga, dan mengerjakan tugas kantor. Ketiga informan tersebut juga memilih pola konsumsi saat berkunjung ke kafe melalui intensitas kedatangannya ke Excelso secara terus menerus. Meskipun intensitas informan yang datang ke kafe tidak sesering informan yang datang ke kedai kopi dan ke warung kopi seperti halnya hanya satu minggu sekali namun mereka cukup rutin untuk melakukan aktivitas nongkrong atau ngopi di kafe.

"Yang paling sering adalah berdiskusi, baik soal usaha, soal politik maupun ya temu kangen dengan kerabat atau saudara itu kita pasti mencari coffee shop. Kalau dulu mungkin kita pengen minum kopi gitu ya kalau kesana, tapi kalau sekarang malah engga, jadi kita datang kesana karena ada keperluan sehingga coffee shop menjadi sebuah tujuan. "(Informan 1, Gus Yani, Wawancara, Jumat, 27 Maret 2020).

Penggunaan media sosial bagi pengunjung kafe juga beragam, hal ini ditentukan oleh usia. Bagi pengunjung yang tergolong muda, mereka aktif membagikan momen ngopi kedalam media 
sosial yang mereka miliki misalnya Instagram, dan bagi pengunjung yang mengunggah kedalam media sosial yang dimilikinya mereka cenderung hanya iseng dan hanya ingin mengabadikan momen saja. Namun bagi pengunjung yang usianya di atas 40 tahun, mereka cenderung tidak aktif dalam media sosial sehingga tidak mengunggah momen apapun.

"Hmmm ya sering sih. Kayak contohnya saya story, instastory di Instagram, gitu. Sama siapa gitu, saya foto terus saya share di Instagram." (Informan 3, Yayan, Wawancara, Jumat, 27 Maret 2020).

Bagi informan pengunjung kafe saat melakukan aktivitas nongkrong ataupun ngopi mereka menghabiskan mengeluarkan uang sekitar 100.000-300.000 ribu rupiah tergantung produk apa saja yang mereka beli. Peran barista dalam menyajikan produk, peneliti juga mendapatkan jawaban yang beragam. Bagi pengunjung yang berusia cenderung muda, tentu mereka mempertimbangkan skill barista dalam menyajikan produk kopi, bahkan mereka menganggap bahwa skill barista itu menentukan merek sebuah kafe itu sendiri. Pengunjung yang usianya berkisar di atas 40 tahun mereka cenderung tidak terlalu mementingkan skill barista, melainkan mereka akan mementingkan pelayanan barista dalam kafe tersebut karena menurutnya pelayanan barista yang dinilai cukup baik dapat menambahkan kesan nyaman saat mengunjungi sebuah kafe.

"Jadi tergantung ya berapa banyak orang yang ikut ketemu di coffee shop, yang pasti bisa sampe 100-300 ribu, tapi ya kalau orangnya banyak banget bisa lebih-lebih, karna kan coffee shop sekarang bukan jual kopi aja tapi ada makanannya juga." (Informan 1, Gus Yani, Wawancara, Jumat, 27 Maret 2020).

Tabel 2. Hasil Pola Konsumsi Pengunjung Cafe Excelso

\begin{tabular}{|c|c|}
\hline & Pengunjung Kafe Excelso \\
\hline Alasan memilih tempat ngopi & Kenyamanan dan kualitas produk yang bagus. \\
\hline Aktivitas yang dilakukan & $\begin{array}{l}\text { Rapat organisasi, bertemu rekanan kerja, menghabiskan } \\
\text { waktu dengan keluarga, dan mengerjakan tugas kantor. }\end{array}$ \\
\hline $\begin{array}{l}\text { Intensitas dan durasi saat ngopi } \\
\text { berlangsung }\end{array}$ & $\begin{array}{l}\text { Satu minggu sekali dan pengunjung berada di excelso } \\
\text { selama }\end{array}$ \\
\hline Biaya yang dikeluarkan & $100.000-300.000$ rupiah. \\
\hline Mengunggah di media sosial saat & $\begin{array}{l}\text { Pengunjung yang tergolong masih berusia muda aktif } \\
\text { mengunggah momen ngopi dalam media sosial instagram. }\end{array}$ \\
\hline
\end{tabular}




\begin{tabular}{|c|c|}
\hline ngopi & $\begin{array}{l}\text { Namun pengunjung yang usianya tergolong cukup tua, } \\
\text { mereka cenderung tidak aktif dalam media sosial }\end{array}$ \\
\hline $\begin{array}{l}\text { Perasaan yang diharapkan saat } \\
\text { mengunggah di media sosial }\end{array}$ & Hanya iseng dan hanya ingin mengabadikan momen \\
\hline $\begin{array}{c}\text { Tanggapan desain, interior dan } \\
\text { dekorasi yang dapat membuat } \\
\text { nyaman }\end{array}$ & $\begin{array}{l}\text { Pemilihan kursi dan meja, dekor dinding, hiasan di sekitar } \\
\text { kafe, alunan musik juga ruangan yang dingin. Bahkan tak } \\
\text { jarang dari mereka yang sengaja memilih duduk di sofa } \\
\text { demi rasa nyaman. }\end{array}$ \\
\hline Tanggapan mengenai fasilitas lain & 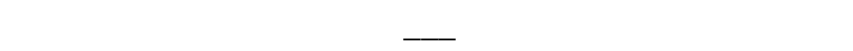 \\
\hline $\begin{array}{l}\text { Skill barista menentukan merek } \\
\text { tempat } n g o p i\end{array}$ & $\begin{array}{c}\text { Bagi pengunjung yang berusia cenderung muda, mereka } \\
\text { mempertimbangkan skill barista dalam menyajikan produk } \\
\text { kopi, bahkan mereka menganggap bahwa skill barista } \\
\text { menentukan merek sebuah kafe itu sendiri. Namun bagi } \\
\text { pengunjung yang usianya tergolong cukup tua, mereka tidak } \\
\text { begitu mempertimbangkan skill barista. }\end{array}$ \\
\hline
\end{tabular}

Sumber: Hasil Wawancara Penelitian

\section{Pola Konsumsi Konsumen Kedai Kopi}

Aktivitas nongkrong merupakan sebuah pola ragam budaya yang saat ini sedang eksis di Indonesia. Keberagaman pola tersebut dapat ditinjau melalui sikap, nilai dan cara hidup suatu kelompok tertentu, hal ini dipahami menjadi sebuah bentuk aktivitas tertentu yang sudah menjadi kebiasaan yaitu aktivitas nongkrong (Fauzi et al., 2017)

Apabila pada subbab sebelumnya telah dijelaskan bahwa kini seiring dengan berkembangnya zaman dan lahirnya masyarakat urban, para penikmat kopi dapat menikmati secangkir kopi di dalam kafe-kafe yang mengusung konsep modern, yang mana dapat menawarkan sensasi berbeda saat orang-orang ingin menikmati secangkir kopi. Di Kota Gresik juga banyak terdapat kedai-kedai kopi di pinggiran jalan yang menjual produk tidak jauh beda dengan produk yang di jual di kafe. Selain kafe, hadirnya kedai kopi saat di era modern saat ini juga memberikan warna baru bagi para penikmat kopi di Indonesia, khususnya Kota Gresik. Kedai kopi saat ini menjual produk minuman yang tidak jauh beda bahkan hampir sama dengan produk yang dijual di kafe namun dengan harga relatif lebih murah. Meskipun tempat yang disediakan cenderung lebih sederhana dibandingkan kafe, namun kedai kopi saat ini juga banyak di datangi oleh pengunjung. Biasanya konsumen kedai kopi ini relatif anak-anak muda. Salah satu kedai kopi yang memiliki banyak konsumen anak-anak muda adalah Kedai Kene Kopi.

Berdasarkan hasil wawancara dari informan mengenai pola konsumsi konsumen pengunjung kedai kopi khususnya Kene Kopi, dapat diketahui bahwa konsumen yang mendominasi adalah kalangan anak-anak muda. Mereka datang untuk nongkrong di kedai kopi 
karena kedai kopi menyediakan tempat yang nyaman dan harganya relatif lebih murah dibanding nongkrong di kafe dan dengan adanya beberapa fasilitas seperti wifi, musik pengiring yang enak, dan colokan listrik juga membuat ketertarikan yang lebih bagi para anak muda. Kenyamanan yang dimaksud oleh informan adalah kedai kopi dapat menyediakan kursi dan meja yang layak, kemudian ruangan yang dingin serta tempat yang bersih. Meskipun beberapa dari mereka tidak banyak yang terlalu mementingkan desain interior dan dekorasi, namun adanya meja dan kursi yang layak sudah dapat memberikan kenyamanan bagi para pengunjung.

\begin{abstract}
"Karena tempatnya nyaman, enak dan friendly aja."
"Harganya lebih kayak warung, rasanya lebih kayak kafe sih sebenere."

"Yang pertama emang karena tempatnya yang enak, nyaman. Didukung sama musik yang bisa nenangin pikiran, sama produknya juga enak sih." (Informan 4, Raka, Wawancara, Sabtu, 21 Maret 2020).
\end{abstract}

Kemudian harga yang murah dengan kualitas produk mirip dengan yang di jual di kafe juga menjadi alasan yang cukup penting bagi para anak-anak muda memilih nongkrong di kedai kopi. Adanya promo juga membuat para pengunjung kedai kopi dapat membeli produk dengan harga lebih murah dengan produk dan rasa yang tetap berkualitas.

\begin{abstract}
"Karena saya kan masih pelajar ya kak, sangu-nya (uang saku) ga banyak haha, jadi saya suka cari minuman yang ada promonya. Kayak misalkan di Kene Kopi itu kan banyak promo, biasanya gitu. Terus rasanya enak juga."

"Suka rasanya kak. Kan saya ga seberapa suka kopi, Kalau Kene Kopi ini kopinya nggak terlalu kuat, manisnya juga ada. Terus kemudian selain rasa, juga murah haha, banyak promo." (Informan 6, Wika, Wawancara, Senin, 30 Maret 2020).
\end{abstract}

Kemudian adanya fasilitas seperti wifi dan stop kontak juga dirasa penting bagi mahasiswa yang hendak datang ke kedai kopi untuk mengerjakan tugas. Dari ketiga informan pengunjung kedai kopi hampir dari mereka datang ke kedai kopi untuk sekedar nongkrong ataupun berdiskusi dengan teman-temannya, namun ada juga yang datang untuk mengerjakan tugas, dan hampir dari ketiga informan, mereka selalu datang ke kedai kopi bersama teman-temannya. Intensitas kedatangan pengunjung kedai kopi sendiri di rasa lebih sering dibanding dengan pengunjung kafe, lantaran dalam seminggu mereka bisa datang 2-3 kali. Dari beberapa aktivitas tersebut dapat diketahui bahwa tindakan mereka saat berada di kedai kopi dapat menunjukkan pola konsumsi pengunjung kedai kopi pada umumnya. Selain itu juga bagi pengunjung kedai kopi yang mayoritas merupakan anak-anak muda, mereka sering membagikan momen nongkrong ke dalam media sosial miliknya, seperti halnya Instagram, WhatsApp Story, dan Twitter. Tujuan mereka membagikan momen ngopi semata-mata hanya untuk kepuasan diri. 
"Iya, sih, sering. Sering aku upload foto di media sosial, Instagram juga paling sering dari Instagram stories, kemudian aku juga tag-tag @kenekopi juga biasanya di-repost kan sama akunnya." (Informan 6, Wika, Wawancara, Senin, 30 Maret 2020).

Bagi informan pengunjung kedai kopi, saat melakukan aktivitas nongkrong ataupun $n g o p i$ mereka mengeluarkan uang sekitar 15.000-30.000 rupiah tergantung jenis produk minuman yang mereka beli, juga apabila mereka datang saat adanya promo, mereka dapat mendapatkan segelas minuman dengan harga yang lebih murah.

"Cuma ini, sih. Cuma 18.000 biasanya yang tak pesen itu matcha." (Informan 5, Fira, Wawancara, Selasa 24 Maret 2020).

"Kalau biasanya aku pesan itu harganya 18.000, Kak. Jadi kalau aku beli dengan harga 18.000 biasanya itu pakai dipotong diskon itu, uniform day 25\% biasanya jadi 14.500 terus 15.000, gitu." (Informan 6, Wika, Wawancara, Senin, 30 Maret 2020).

Kemudian mengenai peran barista bagi pengunjung kedai kopi dianggap sangat penting. Dari ketiga informan, mereka sepakat bahwa skill barista dapat menentukan sebuah merek kedai kopi karena rasa produk dapat ditentukan oleh barista, selain itu juga skill komunikasi barista juga dirasa penting karena dapat memudahkan konsumen dalam melakukan pemesanan produk.

Tabel 3. Hasil Pola Konsumsi Pengunjung Kedai Kene Kopi

\begin{tabular}{|c|c|}
\hline & Pengunjung Kedai Kene Kopi \\
\hline Alasan memilih tempat ngopi & $\begin{array}{l}\text { Menyediakan tempat yang nyaman dan harga produknya } \\
\text { relatif lebih murah dibanding nongkrong di kafe dan } \\
\text { dilengkapi dengan beberapa fasilitas lainnya. }\end{array}$ \\
\hline Aktivitas yang dilakukan & $\begin{array}{c}\text { Sekedar nongkrong, berdiskusi dengan teman dan } \\
\text { mengerjakan tugas. }\end{array}$ \\
\hline $\begin{array}{l}\text { Intensitas dan durasi saat ngopi } \\
\text { berlangsung }\end{array}$ & Dalam pengunjung datang 2-3 kali. \\
\hline Biaya yang dikeluarkan & 15.000-30.000 rupiah \\
\hline $\begin{array}{l}\text { Mengunggah di media sosial saat } \\
\text { ngopi }\end{array}$ & $\begin{array}{l}\text { Bagi pengunjung kedai kopi yang mayoritas merupakan } \\
\text { anak-anak muda, mereka sering membagikan momen } \\
\text { nongkrong ke dalam media sosial miliknya, seperti halnya } \\
\text { Instagram, Whats App Story, dan Twitter. }\end{array}$ \\
\hline
\end{tabular}


Perasaan yang diharapkan saat mengunggah di media sosial

Tanggapan desain, interior dan dekorasi yang dapat membuat nyaman
Untuk kepuasan diri sendiri.

Kenyamanan yang dimaksud adalah kedai kopi dapat menyediakan kursi dan meja yang layak, kemudian ruangan yang dingin serta tempat yang bersih. Meskipun beberapa dari mereka tidak terlalu mementingkan desain interior dan dekorasi, namun adanya meja dan kursi yang layak sudah dapat memberikan kenyamanan bagi para pengunjung.

Adanya wifi dan dilengkapi dengan stop kontak.

Skill barista bagi pengunjung kedai kopi dianggap sangat penting. Dari ketiga informan, mereka sepakat bahwa skill barista dapat menentukan sebuah merek kedai kopi karena rasa produk dapat ditentukan oleh barista,

Sumber: Hasil Wawancara Penelitian

\section{Pola Konsumsi Konsumen Pengunjung Warung Kopi}

Setiap individu memiliki pola konsumsi yang berbeda-berbeda. Tentunya orang yang berpenghasilan lebih tinggi akan memiliki pola konsumsi yang berbeda dengan orang yang memiliki penghasilan lebih rendah. Salah satu aktivitas yang sangat identik dengan masyarakat urban lifestyle saat ini adalah kegiatan berkumpul dan melibatkan penbicaraan didalamnya (nongkrong). Aktivitas nongkrong dapat dipahami sendiri bagi setiap pelakunya bahwa nongkrong dapat dipahami sebagai media penghibur diri sendiri dan berkespresi, ada juga yang menganggap sebagai sarana bersosialisasi (Fauzi et al., 2017). Hal inipun juga dapat dijumpai pada pengunjung yang sering mendatangi warung kopi.

Apabila aktivitas nongkrong ini sering dilakukan di Kafe dan kedai kopi, sesungguhnya aktivitas nongkrong di warung kopi sudah lebih dahulu ada sejak dulu. Seperti halnya Kota Gresik. Menurut Ayos (2014) awalnya Gresik merupakan wilayah pesisisr yang sangat penting, dari sinilah ngopi muncul karena ngopi menjadi sebuah kebutuhan bagi para pelaut yang singgah (Ayos, 2014). Aktivitas meminum kopi yang awalnya adalah sebuah kebutuhan bagi pelaut yang singgah di Gresik, kini menjadi gaya hidup, bahkan sudah diaggap sebagai budaya yang melekat bagi masyarakat Gresik. Aktivitas yang terjadi didalamnya pun juga sangat beragam. Masyarakat urban saat ini memiliki tujuan yang beragam saat datang ke warung kopi, misalnya seperti berkumpul dengan teman atau kerabat, bersosialisasi, rapat, atau bahkan hanya ingin duduk santai sambil menikmati secangkir kopi untuk menghilangkan penat.

Berdasarkan kutipan wawancara dari ketiga informan mengenai pola konsumsi konsumen pengunjung Warung Kopi Cak $\mathrm{Ri}$ dapat diketahui bahwa para individu tersebut dapat 
menggambarkan bahwa mereka memilih menghabiskan waktu untuk nongkrong atau melakukan aktivitas ngopi di Warung Kopi Cak Ri. Meskipun warung kopi lebih sederhana dibandingkan kafe dan kedai kopi, namun warung kopi juga masih banyak menarik minat pelanggan. Pengunjung warung kopi merasa betah untuk nongkrong di Warung Kopi Cak Ri karena merasa nyaman, harga murah dan kopinya terkenal khas dan enak. Bagi pengunjung warung kopi mereka sama sekali tidak mementingan desain interior dan dekorasi, namun kenyamanan dapat dirasa melalui tempat yang luas, bersih dan angin sejuk yang dapat masuk. Kemudian produk kopi yang khas dapat membuat pengunjung warung kopi tidak berhenti membeli dan mengunjungi warung kopi, khususnya Warung Kopi Cak Ri. Produk yang memiliki rasa khas dan enak ditambah tempat yang nyaman membuat pengunjung warung kopi betah untuk berlama-lama menghabiskan waktunya duduk di warung kopi, bahkan mereka telah menganggap hal tersebut sebagai kebiasaannya dalam kehidupan sehari-hari.

"Karena di warung kopi, tempatnya lebih nyantai untuk ngobrol sama temen, lalu sudah cocok kebiasaan juga buat ngopi di warung." (Informan 7, Amung, Wawancara, Minggu, 1 Maret 2020).

"Karena ngopi di warung kopi itu relatif murah dan kopinya Cak Ri itu khas banget rasanya, selain itu juga kita bisa ketemu sama banyak kalangan." (Informan 7, Amung, Wawancara, Minggu, 1 Maret 2020).

Bagi informan warung kopi mereka memiliki aktivitas seperti halnya datang ke warung kopi untuk sekedar ngobrol dengan teman, bermain game, bahkan untuk rapat dengan klien. Ketiga informan tersebut juga dapat menunjukkan pola konsumsi mereka saat datang ke warung kopi melalui intensitas kedatangannya ke warung kopi secara terus-menerus.

"Iya, sangat menjadi gaya hidup."

"Jadi kalau nganggur dikit ngopi, dan itu terjadi hampir setiap hari, bahkan bisa sehari 3 kali buat ngopi." (Informan 8, Faisal, Wawancara, Selasa, 3 Maret 2020).

"Kalo untuk aku sendiri itu ngobrol, lebih seneng ngobrol daripada nge-game, ya sekali nge-game juga, tapi kalo kebanyakan yang lain sih ya itu nge-game" (Informan 8, Faisal, Wawancara, Selasa, 3 Maret 2020).

Peran media sosial bagi para pengunjung warung kopi juga tidak begitu penting, lantaran bagi para pengunjung Warung Kopi Cak Ri, mereka jarang mengunggah momen ngopi di media sosial yang mereka miliki. Dari ketiganya mereka selalu menyempatkan untuk mengunjungi Warung Kopi Cak Ri setiap harinya. Bahkan pengunjung Warung Kopi Cak Ri umumnya menghabiskan waktu 3-7 jam untuk ngopi di Warung Kopi Cak Ri, hal tersebutlah yang menjadikan konsumsi secara terus menerus menjadi sebuah budaya.

"Yaaa kira-kira satu hari 2 kali, kalau disana sih bisa 4-7 jam aku ada di Warung Kopi Cak Ri." (Informan 9, Alif, Wawancara, Selasa, 3 maret 2020). 
Bagi informan pengunjung Warung Kopi Cak Ri, saat melakukan aktivitas nongkrong ataupun ngopi mereka mengeluarkan uang sekitar 10.000-35.000 rupiah, biaya yang mereka keluarkan tergantung dari produk apa saja yang mereka beli. Kemudian mengenai peran barista, dalam warung kopi tidak ada istilah barista namun disana terdapat pelayan yang biasa membuat atau meracik kopi bagi konsumen. Bagi pengunjung warung kopi, mereka tidak mementingkan skill barista atau pelayan. Hanya saja terkadang beberapa dari pengunjung merasa bahwa berbeda pelayan yang mengaduk kopi, berbeda pula rasanya.

"Untuk ngopinya sendiri hanya 5000-6000 tapi tambahannya kayak rokok ya 20.000, jadi biasa ngehabisin uang kurang lebih 30.000.” (Informan 8, Faisal, Wawancara, Selasa, 3 Maret 2020).

Tabel 4. Hasil Pola Konsumsi Pengunjung Warung Kopi Cak Ri

\begin{tabular}{|c|c|}
\hline & Pengunjung Warung Kopi Cak Ri \\
\hline Alasan memilih tempat ngopi & $\begin{array}{c}\text { Merasa nyaman, harga murah dan kopinya terkenal khas dan } \\
\text { enak. }\end{array}$ \\
\hline Aktivitas yang dilakukan & $\begin{array}{l}\text { Berkumpul dengan teman dan kerabat, bermain game dan } \\
\text { rapat dengan klien. }\end{array}$ \\
\hline $\begin{array}{l}\text { Intensitas dan durasi saat } n g o p i \\
\text { berlangsung }\end{array}$ & $\begin{array}{l}\text { Pengunjung dapat datang setiap hari dan dalam sehari } \\
\text { umumnya mereka menghabiskan waktu } 3-7 \text { jam untuk } \\
\text { ngopi di Warung Kopi Cak Ri. }\end{array}$ \\
\hline Biaya yang dikeluarkan & $10.000-35.000$ rupiah. \\
\hline $\begin{array}{l}\text { Mengunggah di media sosial saat } \\
\qquad n g o p i\end{array}$ & $\begin{array}{l}\text { Peran media sosial bagi para pengunjung warung kopi juga } \\
\text { tidak begitu penting, lantaran bagi para pengunjung Warung } \\
\text { Kopi Cak Ri, mereka jarang mengunggah momen ngopi di } \\
\text { media sosial yang mereka miliki. }\end{array}$ \\
\hline $\begin{array}{l}\text { Perasaan yang diharapkan saat } \\
\text { mengunggah di media sosial }\end{array}$ & - \\
\hline $\begin{array}{l}\text { Tanggapan desain, interior dan } \\
\text { dekorasi yang dapat membuat } \\
\text { nyaman }\end{array}$ & $\begin{array}{l}\text { Pengunjung warung kopi tidak mementingan desain interior } \\
\text { dan dekorasi, namun kenyamanan dapat dirasa melalui } \\
\text { tempat yang luas, bersih dan angin sejuk yang dapat masuk. }\end{array}$ \\
\hline
\end{tabular}


Skill barista menentukan merek tempat $n g o p i$
Warung kopi tidak ada istilah barista namun disana terdapat pelayan yang biasa membuat atau meracik kopi bagi konsumen. Bagi pengunjung warung kopi, mereka tidak mementingkan skill barista atau pelayan. Hanya saja beberapa dari pengunjung merasa bahwa berbeda pelayan yang mengaduk kopi, berbeda pula rasanya.

Sumber: Hasil Wawancara Penelitian

\section{PENUTUP}

Berdasarkan hasil penelitian yang telah dilakukan, terdapat beberapa poin penting yang dapat disimpulkan berdasarkan analisis yang telah dilakukan. Yang pertama Konsumen pengunjung kafe sering kali mementingkan rasa nyaman dan kualitas produk yang baik. Mereka rela mengeluarkan uang sebesar 100-300 ribu untuk nongkrong di kafe demi rasa nyaman dan mengonsumsi produk yang sudah terjamin memiliki kualitas baik. Kedua rata-rata konsumen pengunjung Kedai Kene Kopi merupakan anak-anak muda. Mereka datang untuk nongkrong di kedai kopi karena kedai kopi menyediakan tempat yang nyaman dengan harga murah dan banyak promo namun kualitas produk tidak jauh berbeda dengan yang dijual di kafe dengan adanya beberapa fasilitas seperti wifi, musik pengiring yang enak, dan colokan listrik juga membuat keterterikan yang lebih bagi para anak muda. Dalam sekali mengunjungi kedai kopi, mereka mengeluarkan biaya sekitar 15.000-30.000 rupiah. Yang ketiga pengunjung memiliki latar belakang yang sangat beragam, dan umumnya pengunjung Warung Kopi Cak Ri ini berjenis kelamin laki-laki. Hingga saat ini warung kopi masih banyak menarik minat pelanggan. Pengunjung warung kopi merasa betah untuk nongkrong di Warung Kopi Cak Ri karena merasa nyaman, harga minuman yang murah dan kopinya terkenal khas dan enak di Kota Gresik. Bagi pengunjung warung kopi mereka sama sekali tidak mementingan desain interior dan dekorasi, namun kenyamanan dapat dirasa melalui tempat yang luas, bersih dan angin sejuk yang dapat masuk.

Secara garis besar dapat disimpulkan bahwa pola konsumsi konsumen pengunjung kafe, kedai kopi dan warung kopi memiliki gambaran tindakan yang berbeda-beda. Meskipun seluruh pengunjung baik pengunjung kafe, kedai kopi ataupun warung kopi sama-sama mementingkan kenyamanan saat mengunjungi tempat ngopi, namun mereka memiliki standar kenyamanannya masing-masing seperti halnya yang telah dijelaskan sebelumnya. Juga tidak hanya kenyamanan, pengunjung kafe, kedai kopi ataupun warung kopi juga memiliki pola hidupnya masing-masing, yang mana hal tersebut mengacu pada bagaimana pengunjung atau konsumen memilih untuk menghabiskan waktunya, aktivitas yang dilakukan, dan biaya yang dikeluarkan serta bagaimana seseorang tersebut dapat mencapai kesenangan dan kepuasan dirinya sendiri saat berada di kafe, kedai kopi ataupun warung kopi. 


\section{DAFTAR PUSTAKA}

Anggito, A., \& Setiawan, J. (2018). Metodologi Penelitian Kualitatif. CV Jejak.

Ayos, P. (2014). Menyelami Budaya Ngopi Gresikan. Intisari.Grid.Id. https://intisari.grid.id/read/0332687/menyelami-budaya-ngopi-gresikan?page=all

Baihaqi, A., \& Sofyan, I. (2017). Potret Warung Kopi di kawasan Kota Gresik sebagai Media Ruang Publik. 71-76.

Creswell, J. W. (2014). Research design pendekatan kualitatif, kuantitatif, dan mixed. Pustaka Pelajar.

Dhohiri, T. R. (2007). Sosiologi (Suatu Kajian Kehidupan Masyarkat). Ghalia Indonesia.

Fauzi, A., Puniah, I. N., \& Kamajaya, G. (2017). Budaya Nongkrong Anak Muda di Kafe (Tinjauan Gaya Hidup Anak Muda Di Kota Denpasar). Jurnal Ilmiah Sosiologi, 1(1), 1-13.

Halik, A. A., Kasiyati, S. B., Budiarti, E. B., \& Halik, R. (2015). IbM PENGEMBANGAN USAHA WARUNG KOPI DIDESA BUNGAH DAN DESA LASEM, KABUPATEN GRESIK. Jurnal Pengabdian LPPM Untag Surabaya, 1(02), 97-104. https://doi.org/https://doi.org/10.30996/jpm17.v1i02.526.g481

Harahap, R. F. (2013). Dampak Urbanisasi Bagi Perkembangan Kota di Indonesia. Jurnal Society, 1(1), 35-34.

Sjahroni, H. B., Djunaedi, E., \& Noveria. (2019). Ekonomi Mikro. Deepublish.

Sunajaya, W. (2017). Perencanaan dan Perancangan Perpustakaan Umum yang Sesuai Dengan Gaya Hidup Urban di Surabaya. Seminar Nasional Ilmu Terapan (SNITER). 